INTERNATIONAL JOURNAL OF MULTIDISCIPLINARY RESEARCH AND ANALySis

ISSN(print): 2643-9840, ISSN(online): 2643-9875

Volume 05 Issue 02 February 2022

DOI: 10.47191/ijmra/v5-i2-44, Impact Factor: 6.072

Page No. 556-563

\title{
The Impact of Belief, Attitude and Subjective Norm on OCOP Products Purchase Intention of Vietnamese Consumers
}

\author{
Phan Thi Thanh $\mathrm{Hoa}^{1}$, Nguyen Le Kim Ngan ${ }^{2}$, Nguyen Le Phuong Nga ${ }^{3}$, Trinh Ngoc Anh ${ }^{4}$, Nguyen \\ Thi Thuy Linh 5 \\ ${ }^{1}$ Lecture, Department of Business Administration, National Economics University, Hanoi, Vietnam \\ 2,3,4,5 Student, Department of Business Administration, National Economics University, Hanoi, Vietnam
}

\begin{abstract}
We do research about the impact of belief, attitude and subjective norm on OCOP (one community one product) products purchase intention of Vietnamese consumers. OCOP (abbreviated in English as One commune one product). In Vietnamese sense, each commune (ward) has a product. More specifically, developing the form of organization of production and trading of traditional and advantageous products in rural areas. Through testing with the fixed effects model (FEM) and random effects model (REM), we found that belief, attitude and social influence have positive impacts on the products purchase intention. Specifically, belief has the greatest impact on OCOP purchase intention of Vietnamese consumers.
\end{abstract}

KEY WORD: OCOP, belief, attitude, social influence, purchase intention.

\section{INTRODUCTION}

The OCOP program is an economic development program in rural areas in the direction of developing internal resources and adding value. The program is the solution and task in implementing the national target program on building new rural areas. The focus of the OCOP program is to develop agricultural, non-agricultural products and services that have advantages in each locality along the value chain, driven by private economic sectors (enterprises, producers).

The State plays a constructive role, promulgates the legal framework and policies for implementation; plans orientations for production areas of goods and services; manages and supervises product quality standards; supports the following stages: Training, coaching, technical guidance, application of science and technology, branding, trade promotion, product promotion, credit.

\section{OVERVIEW AND RESEARCH METHODS}

\subsection{Concepts}

\subsubsection{OCOP:}

According to Decision No. 490/QD-TTg issued by the Prime Minister: The OCOP - One commune one product program is a program for economic development in rural areas in the direction of developing internal resources and adding value; is the solution and task in implementing the national target program on building new countryside. The focus of the program is on the development of agricultural, non-agricultural products and services that have advantages in each locality along the value chain, driven by the private sector (enterprises, producer households) and the local economy.

State management agencies play the role of creating and promulgating the legal framework and implementing policies; planning orientations for production areas of goods and services; manage and supervise product quality standards; supporting the following stages: training, coaching, technical guidance, application of science and technology, branding, trade promotion, product promotion, support in building and adding product value, product value chain and key commodities to develop into OCOP products of the province."

In Vietnam, the OCOP program has received and been implemented since 2006 with localities implementing the project "One village, one profession" and started to implement strongly from 2013 onwards with the pioneer province of Quang Nam. The program has contributed to restructuring agricultural production, handicrafts, improving production value and is a unique brand 


\section{The Impact of Belief, Attitude and Subjective Norm on OCOP Products Purchase Intention of Vietnamese Consumers}

of Quang Ninh province. After 3 years of implementation, the province has built 121 products, 99 of which meet the standards of 3-5 stars according to the standards at the provincial OCOP product evaluation contest taking place in May - 2016.

\subsubsection{Belief:}

According to Madhok (1995, p.119), trust is considered as "one party's perception of the possibility that the other party will not act for its own benefit".

According to Böcker and Hanf (2000), trust is defined as a necessary way to reduce uncertainty to an acceptable level and to simplify decisions.

Gefen et al (2003b, p.308) defined trust as "the expectation that the individuals or companies with whom we interact will not take advantage of their advantage to force us to depend on them. It is trusted that stakeholders will behave ethically, reliably, in accordance with social norms, and will deliver on their commitments."

Siergist et al. (2006) defined trust as the certainty that everything was under control and that uncertainty was very low.

According to Magnus Österholm (2010), belief was defined as when a person believed (or has faith) in something to be true. Beliefs were considered to be "subjective, empirical, and often ambiguous" knowledge (Pehkonen \& Pietilä, 2003, p.2) or as personal judgments based on past experiences (Raymond, 1997)., p.552).

Fishbein M. \& Ajzen L. defined a subject's beliefs about an object as the position of that object in the subject's mind based on a judgment of the degree of probability that was beneficial or harmful with respect to an attribute count. Beliefs could be formed in two ways: descriptive beliefs based on actual observations and deductive beliefs based on descriptive beliefs from previous observations.

Trinh Dinh Bay (2002) believed that beliefs included two basic elements: knowledge (experience and reasoning) and emotions. Knowledge depended on the level of perception, while emotions depended on the level of satisfaction of needs and were expressed in negative or positive form. These two factors combined to form trust.

Dang Vu Canh Linh (2008) emphasized in his article that trust is the consequence of the processes of social interaction between people.

In the article by Nguyen Quang Thu and Le Thi Kim Luyen (2017), trust is defined as "the expectation in individuals or compan ies that through interaction will behave in an ethical, trustworthy manner., in line with social norms and will fulfill the commitments that such individuals/companies have made."

\subsubsection{Social influence}

Social influence is a determinant of behavioral intention such as subjective norm according to the theory of TRA (Ajzen, 1991), or TAM (Davis, 1989).

According to Fishbein and Ajzen (1975), subjective norms are defined as an individual's perception, with that individual's key references, that the behavior should or should not be performed. Subjective norms can be measured across the people involved with consumers, defined by normative beliefs for behavioral expectations and personal motivations to perform in accordance with those expectations. (Fishbein \& Ajzen, 1975, p. 16).

According to TRA theory (Fishbein \& Ajzen, 1975), subjective norms can be formed through perceived normative beliefs from people or social factors that influence consumers (such as family, friends, colleagues, media, etc.).

Ajzen (1991) defined subjective norm (Subjective Norms) or social influence as the perception that influencers would think that the individual should or should not perform the behavior. Subjective norms could be described as the individual's perception of societal pressures to perform or not to perform a behavior.

In a 2003 study, Venkatesh et al defined social influence as the degree to which an individual thinks others believe they should use the new system.

In the study of Gefej et al (2003b) and Lin (2007), subjective norms were defined as the opinions of people close to them (such as family, friends and colleagues, celebrities, etc.), consumer trust through individuals directly or through the mass media.

Research by Barkhi et al. (2008) shows that social influence not only has an impact on the purchase intention of customers but also has a significant impact on the consumer's attitude.

According to Teng and Wang (2015), subjective norms are social pressures that affect an individual's perception of performing or not performing a behavior.

The concept of social influence is also mentioned in a number of other studies such as technology adoption and usage patterns (Venkatesh et al., 2012; Venkatesh, 2015) or forecasting in e-commerce (Pavlou \& others). Fygenson, 2006). In this study, social influence is the influence of family, friends... on consumers' purchase intention.

According to Marifa Ham et al (2015), subjective norms are determined by perceived social pressures from others for an individual to behave in a certain way and their motivation to conform to these views of others 


\section{The Impact of Belief, Attitude and Subjective Norm on OCOP Products Purchase Intention of Vietnamese Consumers}

Research by Vu Anh Dung et al (2012a) shows that social factors such as family and social influences are important sources affecting the interest in green products of Vietnamese people. After that, this group of authors (2012b) built and tested the model based on TPB theory (Ajzen, 1991) with the influence of social agents (family, society, government, vehicle, media) besides the attitude to explain the sustainable consumption behavior of Vietnamese people.

\subsubsection{Attitude}

Consumer attitude is an important concept in consumer behavior research. Attitude can be seen as an element of human nature that is formed through the process of learning. People will use attitudes to respond in favor or aversion to a particular object or event. Attitude is not directly observable, but it can be inferred from manifestations of human behavior. For example, positive feelings toward a certain product, often lead to a degree of preference, trust, and ultimately the ability to consume that product. According to Philip Kotler, the attitude describes good or bad evaluations based on persistent perception, these feelings and the tendency of a man's actions to a single person or an idea. The attitude led them to decide whether or not to like someone. According to Ajzen's research (1991), the attitude is the desired process or wish, but from which man gives specific behavior. The attitude is defined as measuring the perception and assessment of the consumer's product, the trades and the properties. According to Schiffman and Kanul (2000), attitude consists of three basic components: (1) cognitive component, (2) emotional component, (3) behavioral tendency component. The cognitive component in the model represents consumers' awareness and knowledge of a certain product, and this awareness comes from their own experiences, collects information from different sources, and thereby forming beliefs about the product and believing that the product will bring some benefits. The emotional component refers to the degree of satisfaction or dissatisfaction, like or dislike, expressed in evaluation. Consumers will rate that product as good or bad, friendly, aversion, etc. And the component of behavioral trends shows the consumer's tendency, intention to act towards the product in the direction that has been perceived and felt.

Another study by author Lobb et al (2007) introduced the SPARTA model, which is an acronym for the following factors: subjective norm $(S)$, perceived behavioral control $(P)$, attitude $(A)$, perceived risk $(R)$, trust $(T)$, and others $(A)$ or other variables such as sociodemographic factors. The proposed model presents the interaction between these factors for purchase intention. Research results have demonstrated that purchase intention is mainly influenced by attitude. Therefore, the results of this study support quite positively that attitude serves as an important determinant of purchase intention.

Some other research results also show that when the consumer's attitude towards environmentally friendly products or green products is positive, the consumer's purchase intention will be more likely to be positive. (Mostafa, 2006 and Mostafa, 2007) and in previous case studies, attitude was found to be the most influential factor in predicting intention (Bagozzi et al., 2000).

The relationship between attitude and intention to buy is also studied by many Vietnamese authors. Research by Nguyen Phong Tuan (2011) also shows that there is a high correlation between attitude towards organic food and purchase intention. This study was conducted in two cities, Hanoi and Ho Chi Minh City, and showed the influence of factors such as attitude towards the environment, perceived value, interest in health, and knowledge about safe food and subjective norms have a clear relationship with the intention to buy safe food of consumers in the South and the North.

According to Le Thuy Huong (2014), Attitude is an individual's positive or negative feelings about performing a certain behavior. Attitude describes the degree to which an individual views the outcome of an action as positive or negative.

\subsection{The impact of attitude, belief and social influence on OCOP products purchase intention}

\subsubsection{The impact of belief on OCOP products purchase intention:}

According to Böcker and Hanf (2000), trust has been identified as a necessary way to reduce uncertainty to an acceptable level and to simplify decisions. Research results of Lobb et al (2007) show that trust in the source of information affects the intention to buy chicken meat in the UK. A recent study by Muringai and Goddard (2018) in Canada, USA and Japan also found that beliefs influence beef and pork consumption. The research results of Stefani et al. (2008) show that general trust positively affects trust in the food supply chain, trust in policy makers and trust in government in schools. Consumption of chicken in Italy. People with high beliefs have more positive attitudes. Research results of Donthu (2001), Elliott and Speck (2005) show that trust positively affects attitude. Research results of Limbu et al (2012) also provide a proof for a positive relationship between beliefs and attitudes.

The program "One Commune One Product - OCOP" is currently one of the levers to promote economic development in rural areas, contributing to speeding up the process of building new rural areas in many provinces and cities. Currently, consumers are more careful in choosing consumer products, in addition to design and durability, they are also especially interested in safety for health, especially in the time of widespread epidemic.

Trust in a product is one of the important factors that determine whether consumers buy and use that product or not. It is not by chance that any business today, whether newly established or has existed for many years, must build and keep consumers' trust 


\section{The Impact of Belief, Attitude and Subjective Norm on OCOP Products Purchase Intention of Vietnamese Consumers}

in that product or brand. If there is any scandal related to product quality, this will quickly reduce consumer confidence in that product. If product quality always meets the requirements of consumers, customers will trust, create brand loyalty and long-term use for the products.

In order to build trust with consumers, the OCOP product evaluation criteria are increasingly strict. OCOP products are evaluated carefully and professionally in many aspects. The evaluation board consists of experts in related fields such as health, environment, ... Not only that, the assessment also goes through many different levels, from district to provincial level, then from province to center OCOP products that meet 4-star standards have important certificates such as VietGap, ISO, ...Consumers are still unfamiliar with the term "OCOP certification", but certifications such as VietGap, ISO, orGlobalGap have been trusted by consumers. Certified products like these help consumers feel secure when shopping.

Currently, the government, ministries and businesses are propagating more about OCOP so that consumers are more familiar with OCOP products, OCOP certified, and trust in the quality of OCOP products. Once consumers put their trust, they are willing to spend money to buy products. From here, it can be seen that the positive impact of trust on OCOP product consumption behavior.

\subsubsection{The impact of social influence on OCOP products purchase intention:}

Ajzen (1991) states that the subjective norm for behavior is the social influence of stakeholders (friends, family, co-workers) of an individual on the performance of a particular behavior. According to TPB theory, subjective norm has a strong and positive influence on action intention (Ajzen, 1991). In a 2012 study, Ha \& Janda showed that subjective norm has positive and moderate effects on green product purchasing behavior. Saleem \& Gopinath (2013) studied the impact of subjective norm on behavioral intention to buy green products. The results show that subjective norm has a positive effect on behavioral intention to purchase green products (Saleem \& Gopinath, 2013). Thus, most of the studies suggest that subjective norm has a positive impact on behavioral intention to purchase green products. However, in a very elaborate study, Kumar (2012) argues that subjective norms do not affect the behavioral intention to buy green products. This is contrary to the TPB theory, but the author does not give specific reasons. From the above analysis, it is shown that the subjective norm for green industrial product purchasing behavior (SNP) has a positive impact on the behavioral intention to purchase green industrial products.

According to Truong Dinh Chien (2015), the subjective norm expressing the level of consumer desire for domestic products depending on the structure of the community or society is collectivism or individualism. core. In Asian countries, including Vietnam, collectivism plays a key role, individuals influence each other strongly and the tendency is often concentrated and easily spreads from person to person. The stronger the degree of intimacy of the stakeholders with the consumer, the greater the influence on their purchasing decision. The greater the consumer's trust in the relevant people, the more their purchasing propensity will be affected. If the judgments tend to be disparaging such as: "The act of buying OCOP products is bragging; OCOP is an unnecessary product for them..." then they will tend to reduce their intention to buy OCOP products. On the contrary, if they feel the support and praise that: "The decision to buy OCOP products is a right one, showing that they care about the quality of life, family, ...", then consumers tend to have higher levels of intention to buy OCOP products.

Social influence has a positive effect on the intention to purchase OCOP products. A typical example is in Thanh Hoa province. Along with the implementation of mechanisms and policies to encourage agricultural and rural development and new rural construction, in recent years, Thanh Hoa province has implemented the Program OCOP submission. Accordingly, departments, branches and localities have flexibly used funding sources to support producers to wake up traditional occupations and develop more new ones, and at the same time strengthen promotion and support for products that are born from the village to reach customers in many difficult markets. Phu Quang lam tea products have appeared and existed on Vinh Loc land for hundreds of years, associated with the life and spirit of the people of Cao Mat village, old Vinh Thanh commune, now Vinh Loc town. Lam tea in Phu Quang land of Vinh Loc also has a brand name on the market, but the annual consumption is quite modest. Since 2018, when provinces and districts have propagated and supported producers under the OCOP Program, families have realized that this is an opportunity to give wings to traditional products to "reach out". Consumption volume reached 25 tons/year, revenue was about 1.5 billion dong, profit was 400 million dong/year, an increase of $20 \%$ compared to before participating in the program. However, the highlight that marks the transcendence of space of Phu Quang blue tea products is that Co.opMart Thanh Hoa Supermarket has selected and put the product "on the shelves" for consumers. Mr. Bui Cong Anh, Deputy Chief of the Office of Coordination of the New Rural Program in the province, said: In order to bring OCOP products to the market, especially into the retail channel system, The office has coordinated with localities, the subject launched 14 points of display, introduction and sale of OCOP products and typical goods from regions and regions. At the same time, fairs have been organized to promote, connect and trade OCOP products, attracting the participation of many cooperatives, businesses, craft villages and farms in the province. Through promotional fairs, dozens of OCOP products that meet the requirements and criteria have been selected and sold at reputable supermarkets and e-commerce platforms. This is the initial success in expanding the consumption market for the 


\section{The Impact of Belief, Attitude and Subjective Norm on OCOP Products Purchase Intention of Vietnamese Consumers}

province's OCOP products... From the example in Thanh Hoa province, it shows that, after the OCOP program was implemented, with the attention and encouragement of the leadership of the province local leadership, sales and propaganda programs are widely deployed and product quality is improved,

From the above analysis, it is shown that the subjective norm for OCOP product purchasing behavior has a positive impact on behavioral intention to purchase OCOP products.

\subsubsection{The relation between social influence, belief, attitude and OCOP products purchase intention:}

According to Ajzen (1991) and O'Neal (2007), subjective norm refers to perceived social pressures to perform or not to perform a behavior. McClelland's theory of needs (1987) suggests that individuals tend to perform behaviors based on the desires of loved ones or reference groups. The effects of subjective norms on purchase intention are also supported in many countries including the US (Shimp and Kavas, 1984), Germany (Bredahl, 2001), UK (Mahon et al., 2006), South Korea (Lee)., 1990) and China (Eves, 2007), ... and studied in areas such as buying organic food (Tarkiaine, 2005), food safety (Chen, 2007).

According to Truong Dinh Chien (2015), subjective standards are the ideal standards that members of that community adhere to as an unwritten essay. Subjective norms reflect beliefs through the opposition/support of those who are most important to an individual (relatives, friends, and those they consider important) when they engage in a particular behavior. body.

Social influence positively affects consumers' beliefs and attitudes.

Continue with the example in Thanh Hoa. Mr. Le Dinh Tu, director of Binh Son agro-forestry cooperative (Trieu Son), said: "From the existing products in the locality, the OCOP program has increased the prestige and quality of the products so that the products can be affirmed in the market. At the same time, motivation can be created for the cooperative to develop new products, increase revenue, and improve the quality of the cooperative's activities.

Currently, with the strong spread of the program, consumers understand, know, identify and identify OCOP products as quality products and brands, so they can rest assured to choose and trust. As a result, the province has developed 16 points of display, introduction and sale of OCOP products and 11 products selected and sold by Co.opMart Supermarkets on supermarket stalls. In addition, the producers are actively promoting and promoting their OCOP products to be widely consumed in the market... From the above analysis, it shows the subjective standards for product purchasing behavior. OCOP has a positive effect on beliefs and attitudes towards OCOP product purchasing behavior.

\section{RESEARCH METHODS}

The main research method used in the model is econometric regression with the general model as follows:

YDTD $=0.514+0.351 \mathrm{NT}+0.218 \mathrm{TD}+0.306 \mathrm{AHXH}+\mathrm{e}$

In which:

YDTD: Dependent variable "OCOP consumption intention"

NT: Independent variable "Belief"

TD: Independent variable "Attitude"

AHXH: Independent variable "Social Influence"

Formal research is a quantitative study. The process of preliminary theoretical research determines the content of issues to be researched, forms research questions and research objectives. From research objectives, research theoretical basis, identify research concepts, develop research hypotheses and research models, then design scales based on research concepts; Research hypotheses and research models are carried out through two preliminary and formal research steps. Preliminary research includes a qualitative study to adjust the scale and a preliminary quantitative study to preliminarily evaluate the scale and adjust the scale accordingly. Formal quantitative research to test the scale and theoretical models.

\section{DATA ANALYSIS}

\subsection{Data description}

The overall research is all Vietnamese consumers living and working in cities. They can be students or those who do many different jobs. Due to limited resources, the author chose 3 big cities representing 3 regions of the country to survey including: Hanoi, Da Nang and Ho Chi Minh City, in which Hanoi and Ho Chi Minh City are the two largest cities and have the highest per capita income in the country.

OCOP businesses always choose Hanoi and Ho Chi Minh City as the place to consume their latest products because these are the two largest consumer markets in Vietnam. In addition, these are also two localities with a large number of immigrants from provinces and cities across the country to live and work, the agility and ability to receive new products are always appreciated. Due to the large scale of the study, the diversity of classification criteria is limited, in terms of resources (financial, time, accessibility...). the group cannot use random sampling method but use random sampling method but use convenience method. 


\section{The Impact of Belief, Attitude and Subjective Norm on OCOP Products Purchase Intention of Vietnamese Consumers}

Although the sample was selected by a convenient method, in order to ensure representativeness, the team tried to evenly distribute the expected number of questionnaires according to 3 localities representing 3 regions of the country, namely Hanoi, Ho Chi Minh City and Hanoi. Ho Chi Minh City and Da Nang. In addition, the group also surveyed consumers by occupation, age, and income level to be able to indicate consumers' intention to use OCOP products.

\subsection{Effects of attitude, belief and social influence on OCOP purchase intention}

The research results show that "Trust" is the factor with the greatest influence (standardized Beta coefficient is 0.32) on "OCOP purchase intention" in the group of 3 extracted factors within the scope of the study.

Research results show that "Social influence" is the factor with the second level of influence (Standardized Beta coefficient is 0.227) on "Intent to consume OCOP program" in the group of 3 influencing factors cited within the scope of the study. OCOP products are products that "require" consumers to also have a certain level of knowledge. Therefore, the "participation", "consultation", "sharing" of family or important people will affect consumers' intention to buy OcOP products.

Research results show that "attitude" is the factor with the lowest influence (standardized Beta coefficient is 0.203) on "Intent to use OCOP program" in the group of 3 extracted factors within the scope of the study. People's attitudes always have many changes over time, at the time of the study, the team analyzed the data and found that this is the least influential factor.

\section{CONCLUSIONS}

Theoretically, the topic identifies the factors affecting the "OCOP consumption intention" of Vietnamese consumers. Those factors include: "Trust", "Attitude", "Social influence". At the same time, the study also determined the intensity and direction of impact of these factors on consumers' intention to use OCOP products. The topic has built and supplemented the basic theory on consumer behavior and OCOP consumption intention of Vietnamese people such as: "Concepts of beliefs, attitudes, social influence". The concept of intention, intention to use OCOP of Vietnamese people. In Conclusion, The factor that has the strongest influence on "OCOP consumption intention" is "Trust". In addition, it also supplements and develops methodology for future studies as well as proposes practical solutions.

In practice, the research results of the topic also suggest to state management agencies, localities and businesses new directions in applying measures to increase trust and popularization to the people to have a more positive and in-depth view of the OCOP program. Specifically, the state management agency has strengthened the implementation of the campaign "Vietnamese people give priority to using Vietnamese goods", and at the same time introduced policies and plans to increase consumers' confidence in OCOP, thereby increasing the intention to purchase OCOP products. Enterprises will have positive changes, transformations and self-improvement from organization, activities to products, thereby actively participating in and contributing to disseminating the image and characteristics of OCOP to friends and partners. For people who intend to use OCOP or who intend to establish businesses participating in OCOP) they will have confidence in the quality and value that OCOP brings.

\section{REFERENCES}

1) Ajzen, I. (1991). The theory of planned behavior. Organizational behavior and human decision processes, 50(2), $179-211$.

2) Antil J.H. (1984), 'Socially Responsible Consumers: Profiles and Implications for Public Policy', Journal of Macromarketing, 5(2), 18-39.

3) Armitage, C. J., \& Conner, M. (2001). Efficacy of the theory of planned behaviour: A meta-analytic review. British journal of social psychology, 40(4), 471-499.

4) Bagozzi, R. P., Wong, N., Abe, S. \& Bergami, M., 2000. Cultural and situational contingencies and the theory of reasoned action: Application to fast food restaurant consumption. Journal of Consumer Psychology, 97-106.

5) Barkhi, R., Belanger, F., \& Hicks, J. (2008). A model of the determinants of purchasing from virtual stores. Journal of Organizational Computing and Electronic Commerce, 18(3), 177-196.

6) 6. Bay, T. D. (2002). Trust and build scientific trust. Thesis of Doctor of Philosophy. Institute of Philosophy, Vietnam Academy of Social Sciences.

7) Böcker, A., \& Hanf, C. H. (2000). Confidence lost and - partially - regained: Consumer response to food scares. Journal of Economic Behavior \& Organization, 43(4), 471-485.

8) Chen, M.-F. (2007). "Consumer attitudes and purchase intentions in relation to organic foods in Taiwan: Moderating effects of food-related personality traits". Food Ouality and Preference, 18, 1008-1021.

9) Donthu, N. (2001). Does your web site measure up? Marketing Management, 10(4), 29-32

10) Dang Vu Canh Linh (2008), Beliefs in a changing world - A sociological analysis of the perceived value and behavior of today's students, Social Science Publishing House, Hanoi. 


\section{The Impact of Belief, Attitude and Subjective Norm on OCOP Products Purchase Intention of Vietnamese Consumers}

11) Elliott, M. T., \& Speck, P. S. (2005). Factors that affect attitude toward a retail web site. Journal of Marketing Theory and Practice, 13(1), 40-51.

12) Fishbein, M. \& Ajzen, I. 1975, Belief, Attitude, Intention, and Behavior: An Introduction to Theory and Research, AddisonWesley, Reading, MA.

13) Fraj-Andres E. \& Martinez-Salinas E. (2007), 'Impact of Environmental Knowledge on Ecological Consumer Behavior: An Empirical Analysis', Journal of International Consumer Marketing, 19(3), 73-102.

14) Gefen, D., Karahanna, E., \& Straub, D. W. (2003b). Inexperience and experience with online stores: The importance of TAM and trust. IEEE Transactions on Engineering Management, 50(3), 307-321.

15) Gupta S. \& Ogden D.T. (2009), 'To Buy or Not to Buy? A Social Dilemma Perspective on Green Buying', Journal of Consumer Marketing, 26(6), 376-391.

16) Ha Hong-Youl \& Janda Swinder (2012), 'Predicting Consumer Intentions to Purchase Energy-Efficient Products', Journal of Consumer Marketing, 29(7), 461-469.

17) Ha Ngoc Thang (2015). Research on factors affecting online shopping intention in Vietnam. PhD thesis, National Economics University.

18) Hoang, T., \& Chu, N. M. N. (2008). Analysis of research data with SPSS-volume 1.

19) Ho Huy Tuu, Nguyen Van Ngoc, Do Phuong Linh (2018). Factors affecting green consumption behavior of people in Nha Trang. KTDN Journal. 103.

20) Kramer, R. M., \& Tyler, T. R. (Eds.). (1996). Trust in organizations: Frontiers of theory and research. Thousand Oaks, CA: Sage.

21) Kumar Bipul (2012), Theory of Planned Behaviour Approach to Understand the Purchasing Behaviour for Environmentally Sustainable Products, Indian Institute of Management, Ahmedabad, India.

22) Laroche M., Bergeron J. \& Barbaro-Forleo G. (2001), 'Targeting Consumers Who Are Willing to Pay More for Environmentally Friendly Products', Journal of Consumer Marketing, 18(6), 503-520.

23) Le Thuy Huong (2014). Research on factors affecting the intention to buy safe food of urban residents - For example in Hanoi city, PhD thesis, National Economics University.

24) Limbu, Y. B., Wolf, M., \& Lunsford, D. (2012). Perceived ethics of online retailers and consumer behavioral intentions: The mediating roles of trust and attitude. Journal of Research in Interactive Marketing, 6(2), 133-154.

25) Lin, H. F. (2007). Predicting consumer intentions to shop online: An empirical test of competing theories. Electronic Commerce Research and Applications, 6(4), 433-442.

26) Liu L. J. Enhancing sustainable development through developing green foods: China's option. First Consum 2003.

27) Lobb, A. E., Mazzocchi, M., \& Traill, W. B. (2007). Modelling risk perception and trust in food safety information within the theory of planned behaviour. Food Quality and Preference, 18(2), 384 - 395

28) Madhok, A. (1995). Revisiting multinational firms' tolerance for joint ventures: a trust-based approach. Journal of International Business Studies, 117-137.

29) Muringai, V., \& Goddard, E. (2018). Trust and consumer risk perceptions regarding BSE and chronic wasting disease. Agribusiness, 34(2), 240-265.

30) Nam, N., \& Huan, N. (2022). The influence of beliefs, attitudes and standards on consumers' intention to buy pork in Ho Chi Minh City. Ho Chi Minh. Retrieved 12 August 2021, from http://jabes.ueh.edu.vn/Content/ArticleFiles/5d60f841fb50-4226-87e4-4f72e49fab66/JABES-2018-4-V251.pdf

31) Ho Hoai Phuong et al., (2021). Consumer confidence in functional foods: A study in the Northern provinces.

32) Nguyen Thi Tuyet Mai, Chau, N. M., Duc, L. M., Mai, P. N., Tran, V. K.H, Ngoc, N. H. \& Hung, P. T. (2018). "Antecedents of purchase intention toward organic food: A study of young consumers in Vietnam" Labor - Society, 176-198.

33) Nguyen, Thanh Huong (2012). Key factors affecting consumer purchase intention - A study of safe vegetable in Ho Chi Minh City, Vietnam, Master of business (Honours), International School of Business, University of Economics, Ho Chi Minh City.

34) Nguyen Dinh Tho, (2011), Scientific research methods in business, Labor - Social Publishing House, Hanoi.

35) Nguyen Quang Thu et al., 2017. The role of social influences in the relationship with beliefs, attitudes, perceived risks to the online purchase intention of consumers in Ho Chi Minh City. Ho Chi Minh.

36) OCOP Nghe An (2022). Decision No. 490/QD-TTg approving the One Commune One Product Program for the period 201820. Retrieved 15 December 2021, from http://ocop.nghean.gov.vn/laws/detail/Quyet-dinh-so-490-QD-TTg-ve-viec-pheduyet-Chuong-trinh-moi-xa-mot-san-pham-giai-doan-2018-202-22/ 


\section{The Impact of Belief, Attitude and Subjective Norm on OCOP Products Purchase Intention of Vietnamese Consumers}

37) Pham Thi Hong Dao (2014). Research on factors affecting consumers' intention to buy safe vegetables in Ho Chi Minh City. Master thesis. University of Economics Ho Chi Minh City.

38) Phan Thanh Hung (2019), Factors affecting the intention to buy organic food of urban Vietnamese consumers. Master thesis. National Economics University.

39) Phong Tuan Nguyen (2011). A comparative study of the intention to buy organic food between consumers in northern and southern Vietnam. AU-GSB e-Journal, 4(2).

40) Ricky Y. \& Chan K. (2001), 'Determinants of Chinese Consumers' Green

41) Saleem Farida \& Gopinath C. (2013), 'Antecedents of Environmental Conscious Purchase Behaviors', Middle-East Journal of Scientific Research 14(7), 979-986.

42) Schiffman, L. G. \& Kanuk, L. L., 2000. Consumer Behavior. Wisconsin: Prentice Hall, 7th edition.

43) Sobhanifard, Y. (2018). "Hybrid modeling of the consumption of organic foods in Iran using explanatory factor analysis and an artificial neural network"., British Food Journal, 120, 44-58.

44) Tarkiainen, A. and Sundqvist, S (2005), "Subjective norms, attitudes and intentions of Finnish consumers in buying organic food", British Food Journal, 107(11): 808-820

45) Teng, C. C. \& Wang, Y. M. (2015). Decisional factors driving organic food consumption: generation of consumer purchase intentions. British Food Journal, 117(3), 1066-1081.

46) Thu, N. Q., \& Tuyen, L. T. K. (2020). The role of social influencing factors in the relationship with beliefs, attitudes, perceived risks to consumers' online purchase intention in Ho Chi Minh City. Ho Chi Minh. Asian Business and Economic Research Journal, 29(1), 38-55.

47) Truong Dinh Chien (2015), "Some theoretical and practical issues in studying the buying behavior of domestic consumers in urban Vietnam", Proceedings of the National Scientific Conference "Vietnamese people's buying behavior towards domestic and foreign goods". in the era of globalization", National Economics University.

48) Venkatesh, V. (2015). Technology acceptance model and unified theory of acceptance and use of technology. Wiley Encyclopedia of Management, 7, 1-9.

49) Venkatesh, V., Morris, M. G., Davis, G. B., and Davis, F. D, 2003. User Acceptance of Information Technology: Toward a Unified View. MIS Quarterly, 17, 425-478.

50) Venkatesh, V., Thong, J. Y. L., \& Xu, X. (2012). Consumer acceptance and use of information technology: Extanding the unified theory of acceptance and use of technology. MIS Quarterly, 36(1), 157-178.

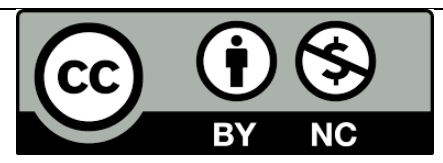

There is an Open Access article, distributed under the term of the Creative Commons Attribution - Non Commercial 4.0 International (CC BY-NC 4.0)

(https://creativecommons.org/licenses/by-nc/4.0/), which permits remixing, adapting and building upon the work for non-commercial use, provided the original work is properly cited. 